\title{
Assessment of optimum thermal humidity index for crossbred dairy cows in Dehradun district, Uttarakhand, I ndia
}

\author{
Shweta Kohli ${ }^{1}$, U. K. Atheya ${ }^{2}$ and A. Thapliyal ${ }^{1}$ \\ 1. Department of Biotechnology, Graphic Era University, Dehradun, Uttarakhand, India; 2. Department of Veterinary \\ Diagnostic, Molecular Biology and Genetic Engineering Center, Dehradun, Uttarakhand, India. \\ Corresponding author: Shweta Kohli, e-mail: shwetakohli4386@gmail.com, \\ UKA: ukatheya@gmail.com, AT: ashish.thapliyal@geu.ac.in \\ Received: 16-07-2014, Revised: 26-09-2014, Accepted: 30-09-2014, Published online: 05-11-2014
}

doi: 10.14202/vetworld.2014.916-921. How to cite this article: Kohli S, Atheya UK, Thapliyal A (2014) Assessment of optimum thermal humidity index for crossbred dairy cows in Dehradun district, Uttarakhand, India, Veterinary World 7(11): 916-921.

\begin{abstract}
Aim: Uttarakhand is a relatively new state and many cross bred cattle were introduced to boost the milk yield of the state. Despite all efforts the milk yield of dairy in Uttarakhand is comparatively low. In our study, we assessed the effect of heat stress on milk production, using thermal humidity index (THI) in high (cross bred cattle) and low milk producing (LMP) cows (native cows) in Dehradun district of Uttarakhand, India.
\end{abstract}

Materials and Methods: Effect of heat stress was measured on high and LMP cross bred cows using THI maintained on standard feeding and nutritional value. Daily ambient temperature and relative humidity were recorded to calculate the THI. Daily milk production was noted to verify the effect of heat stress. Furthermore, profile the thyroid hormones using enzyme-linked immunosorbent assay.

Results: Low yielding cows did not show any significant change when the THI was above 72 from month June to October during stress condition. But high yielding cows shows a significant decrease $(\mathrm{p}<0.05)$ in milk yield when THI was above 80 (severe stress zone) in the month of June to October and milk production decrease from an average of $18 \pm 1.4$ to $10.9 \pm 0.92 \mathrm{~L}$ whereas in November-December when THI declines in the zone of comfort the milk yield did not show significant rise. The thyroid hormones (T3 and T4) level were found lower in summer heat stress condition for a high yielding cattle.

Conclusion: Summer heat stress significantly decreased milk yield in high milk producing (HMP) crossbred cows. As THI rises from comfort zone to stress zone milk yield decreased by $30-40 \%$ and this loss in milk production is irreversible. Management strategies should be needed as environmental control housing is suggested for the HMP crossbred cattle to minimize the heat stress. If all the dairies with cross bred cattle implement these small modifications in housing of cattle, there would be a huge increase in milk production.

Keywords: cross bred dairy cow, heat stress, milk production.

\section{I ntroduction}

The native Indian cows are draft animals and are not economical due to low milk yield. These cows have milk yield 700-1000 L of per lactation that is of 5-7 months. To boost milk production cross bred cattle of Holstein Friesian (HF) cows (above $75 \%$ of the exotic blood) are generally used. These cows have milk yield over on an average $5000 \mathrm{~L}$ per lactation. The comfort zone for native and HF cattle is different [1]. In terms of thermal humidity index (THI), heat stress can be categorized into mild, severe and deadly stress zones as shown in Figure-1. The heat stress is dependent on temperature as well as humidity [2]. District Dehradun is located between latitudes $29^{\circ} 58^{\prime} \mathrm{N}$ and $31^{\circ} 2^{\prime} \mathrm{N}$ and longitudes $77^{\circ} 34^{\prime} \mathrm{E}$ and $78^{\circ} 18^{\prime} \mathrm{E}$. Dehradun has generally temperate climate. The springs here spans from the months March to mid-April. Summer follows the spring season from mid-April to June end. Monsoon starts after June and ends in October. It gets really

Copyright: The authors. This article is an open access article licensed under the terms of the Creative Commons Attributin License (http:// creative commons.org/licenses/by/2.0) which permits unrestricted use, distribution and reproduction in any medium, provided the work is properly cited. humid (about 91\%) at times during monsoon. By November, the winter starts. The problem of heat stress in dairy cattle has recently increased due to the anticipated increase in environmental temperature by global warming [3]. High yielding cattle are susceptible to heat stress [4] and have a negative effect on the physiology of cow and milk production however the native cattle resist $[5,6]$. THI is widely used all over the world to assess the impact of heat stress on dairy cows $[7,8]$. Milk production is not affected by heat stress when mean THI values are ranges 35-72 [9].

At Graphic Era University, Dehradun, Uttarakhand a herd of $40-70$ cows is maintained. In this dairy farm there are HF cattle and these high producing crossbred of HF cows were imported from other state and there they have around 18-20 L of milk yield as per the record maintained over there before transportation (Figure-2). The low milk producers were maintained here from 2 years and their average milk production was around 8-10 L (Figure-2). As research on THI and milk production is limited to non-existing in Uttarakhand.

Our study was aimed to assess the effect of heat stress on milk production of high milk producing 


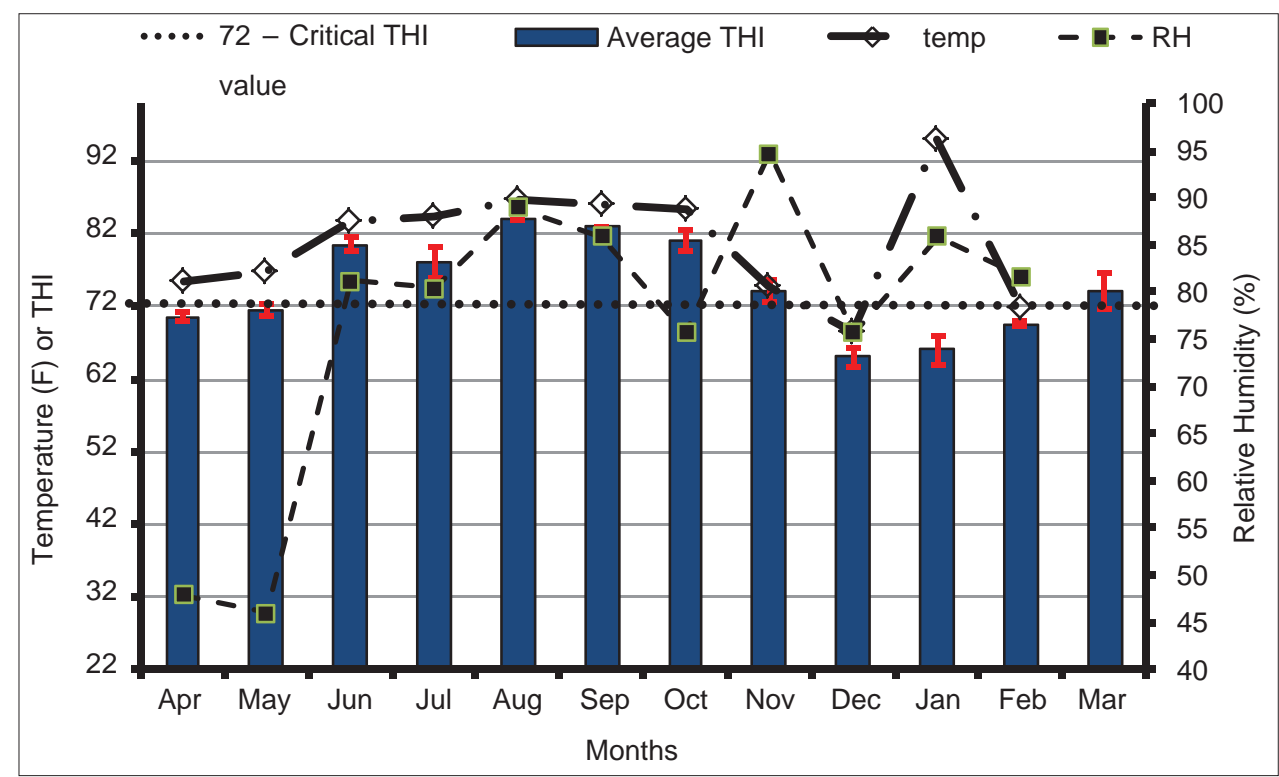

Figure-1: The average temperature, average relative humidity and average of thermal humidity index (THI) values corresponding each month for the period April 2011-March 2012 with the heat stress zones (<72: Zone of comfort, 72-80: Mild stress, 80-85: Severe stress, >85: Deadly stress) and dotted line at shows the critical THI value.

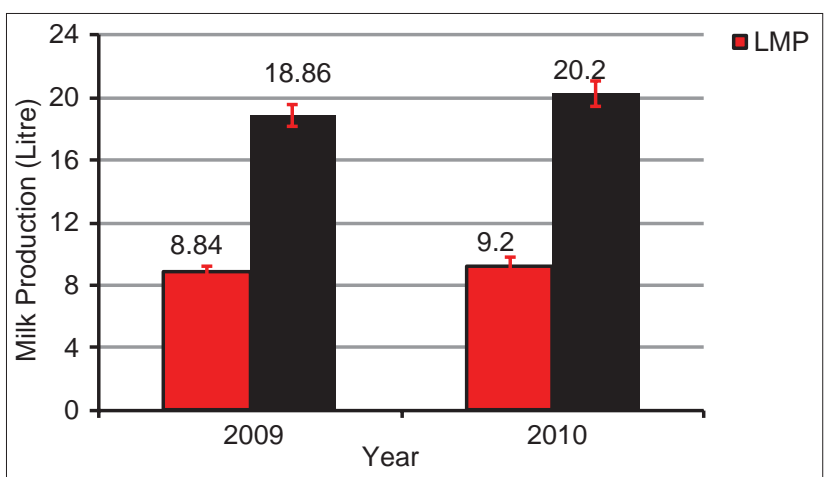

Figure-2: Average milk production of the high milk producing cows and low milk producing cows recorded before the experimental period where the cows were maintained originally for the year 2009 and 2010.

(HMP) cows and low milk producing (LMP) cows and also profile the thyroid hormones to assess the effect of heat stress in Dehradun district, Uttarakhand.

\section{Materials and Methods}

\section{Ethical approval}

Permission was obtained from Institutional Ethics Committee, Graphic Era University, Dehradun for blood sampling and was carried out under the supervision of the veterinary doctor.

\section{Study area}

The graphic Era University of Dehradun, Uttarakhand, India has been maintaining a herd of 40-70 cows containing native cattle and crossbred cattle. The 40 lactating cows were followed for our study and these cows were assigned to two equal groups according to milk production i.e., 20 high milk producers (cross-bred cattle) and 20 low milk producers (native cattle). These cows were maintained on standard feeding, nutrition, breeding and management practices. The cows in both groups were managed similarly. Same green fodder was fed to the cattle of both the groups according to the availability in different season i.e., in the winter months green "burseen" was given mixed with hay and in summer months green "Jawar and maize" was fed mixed with hay. Forage was ad libitum. Additional nutrition of $5 \mathrm{~kg} /$ day per cattle (33\% oil cake, $33 \%$ grain [wheat/maize], 33\% rice bran and $1 \%$ mineral mixture) was also given 2 time a day before milking time in morning $(4 \mathrm{am}, 2.5 \mathrm{~kg}$ nutrition mix) and evening (4 pm, 2.5 kg nutrition mix) daily. Animals were provided free access to fresh and portable water. In the day time, cattle were kept inside in the shed covered with insulated sheets having height of above 14 feet. Fans were also fitted with the supply of generator. In the night, the cows were kept loose. Animals exhibiting heat were inseminated artificially using frozen semen of HF breed. Animal showing signs of diseases were treated by veterinary doctor and proper vaccination was given. The data were collected for a period of 1 year, i.e., from April 2011 to March 2012. Data was recorded in the pen and in the shade. Animal were milked twice daily ( 4 am and $4 \mathrm{pm}$ ). For THI data were recorded at 8 am and 2 pm daily. For thyroid hormone profiling the samples were collected in the summer months (June, July and August i.e., hot and dry) and in winter months (November, December and January i.e., cold and dry).

\section{Sampling procedure}

Blood samples were collected from the jugular vein of the HMP cattle for thyroid hormone analysis. Blood samples were collected 2 times from each cow after an interval of 15 days in the summer month (May, June, and July). Blood sampling was always done between 10 am and 11 am for all cattle. Similar pattern was followed for winter months (November, 
December, and January). A volume of $3 \mathrm{ml}$ blood sample was collected in serum collection tube (Peerless Co., $5 \mathrm{ml})$. The samples were kept in an ice bath maximum for $1 \mathrm{~h}$ until centrifugation at $4^{\circ} \mathrm{C}$ to recover serum. Serum was obtained by centrifugation of blood at $4000 \mathrm{rpm}$ for $20 \mathrm{~min}$ at $4^{\circ} \mathrm{C}$. From the serum collection tube, the serum was drawn and kept in Eppendorf on ice. Then sample brought to the biotech lab of Graphic Era University where it was kept in the refrigerator at $-20^{\circ} \mathrm{C}$ and within 1 week the analyses were done.

\section{THI measurement}

To measure the heat stress, ambient temperature and relative humidity were recorded daily. Temperature was recorded using thermometer, and relative humidity using a hygrometer was recorded twice a day at 8 am and 2 pm at the Graphic Era University dairy. Only maximum values are being reported in the present study. With the help of these two THI value can be calculated for the experiment period using the formula: THI $=$ tair $-(0.55-[0.55 *$ relh/100] $) *($ tairf-58.8) (Buffington et al., 1977) where, THI=Temperaturehumidity index, tair=air temperature in Fahrenheit, relh=percent relative humidity.

\section{Quantification of milk}

Daily milk production was noted after each milking to verify the effect of heat stress on milk production rate. The cows were milked twice a day using milking machines. Milk was measured in liter.

\section{Hormone profiling}

Thyroid hormone level was measured using enzyme-linked immunosorbent assay (ELISA) to assess the effect of heat stress. Blood serums were analyzed for T3 and T4 using ELISA kit (ELISCAN, RFCL).

\section{Statistics}

The data of this study were statistically analyzed using Origin Labs software version 9.1 (OriginLab Corporation, Northampton, USA).

\section{Result}

Table- 1 shows the average monthly THI for each month during the experimental period April, 2011 to

Table-1: Average thermal-humidity index values recorded for the experimental months from April 2011 to March 2012 for the Dehradun district, Uttarakhand.

\begin{tabular}{lc}
\hline Months & THI \pm SE \\
\hline April & $70 \pm 0.82$ \\
May & $71.5 \pm 0.68$ \\
June & $80.5 \pm 1.06$ \\
July & $78 \pm 2.12$ \\
August & $84 \pm 0$ \\
September & $83 \pm 0$ \\
October & $81 \pm 1.41$ \\
November & $74 \pm 1.5$ \\
December & $65 \pm 1.41$ \\
January & $66 \pm 2.0$ \\
February & $69.5 \pm 0.35$ \\
March & $74 \pm 2.47$ \\
\hline
\end{tabular}

$\mathrm{THI}=$ Temperature humidity index, SE=Standard error
March, 2012. In the months of April and May the THI is below the critical THI, i.e. 72. But in the month of June the average THI increases to 80.5 (severe stress zone). After June, it declines to 78 in the month of July but it again shoot up to 84 in the month of August remains above 80 till the month of October. It revealed that there was heat stress condition from the months June to October. Then after monsoon THI declined to 74 in the month of November. In the month of December THI value was calculated 65 (comfort zone) and remains below critical THI (72) till February. In March THI again exceeds 72. Data presented in the Figure- 1 shows the summer heat stress as depicted by the THI in the months from June to October. Average calculated THI variations across each month and the stress zones are shown in Figure-1.

Average milk production recorded during the experimental period for the high milk producers and low milk producers and the effect of heat stress on their milk production was shown in Figures-3 and 4. Figure-3 shows that high yielding cattle milk yield decreased from $18 \pm 1.4$ to $10 \pm 0.92 \mathrm{~L}$ when the THI was above 72 in the months June-October. In the month of November rise in milk yield seen may be due to a sudden drop in air temperature. However again it decreases to $8 \mathrm{~L}$ in the month of December. This whole results that even when the THI value decreased below the critical value 72, milk yield did not rise again in the high yielding cows. Data showed the loss of about $40-44 \%$ of milk yield in the high milk producers. The effect of THI had significant $(\mathrm{p}<0.05)$ effect on average daily milk yield when the cross bred cows were in heat stress. Figure-4 shows effect of heat stress on milk production of LMP cows. Low milk producers did not show any significant loss of milk yield due to increase in THI or heat stress level. No significant loss in milk yield was recorded either the THI value is in severe stress zone or in moderate stress zone.

Thyroid hormones (T3 and T4) checked only for the HMP cattle in summer months and in winter months as shown in Figures-5 and 6. In summer months when the THI was higher or in the severe stress zone the thyroid hormones (T3 and T4) level in blood serum was calculated below the normal range and in the winter month when the THI was below the critical value 72 or in comfort zone the thyroid hormones (T3 and T4) level in blood serum was increased.

\section{Discussion}

Heat stress is one of the most important stressors, and it cannot be indicated only in terms of temperature. The THI combines temperature and humidity in a single value and has been widely used to quantify heat stress in dairy animals [2]. THI was originally developed for humans and extended to cattle [10]. High yielding crossbred cows are more sensitive to hot and humid environment than low yielding cows [4,5] whereas the native cattle were well adapted to these environmental conditions. The higher susceptibility 


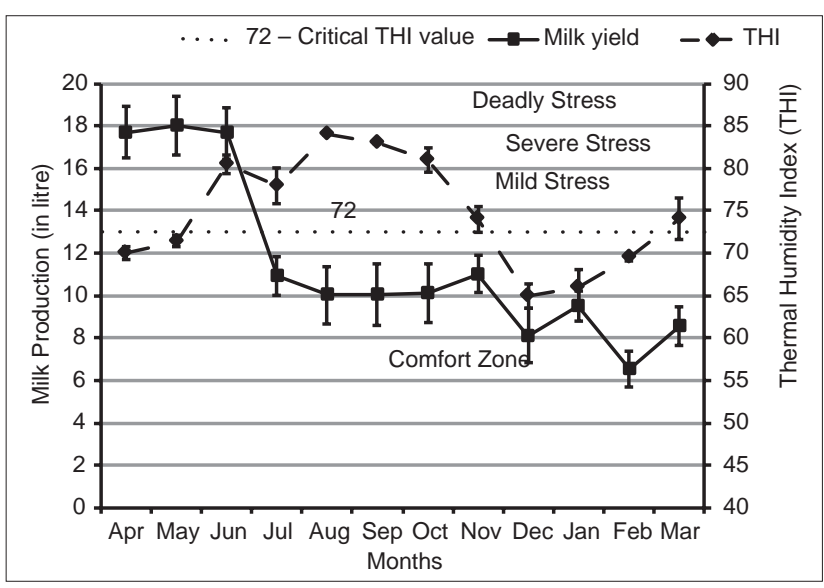

Figure-3: Relation between average milk yield of high yielding cow and average thermal humidity index for the experimental months in Dehradun district of Uttarakhand shows the loss of $8 \mathrm{~L}$ of milk/day per cow and this loss is irreversible.

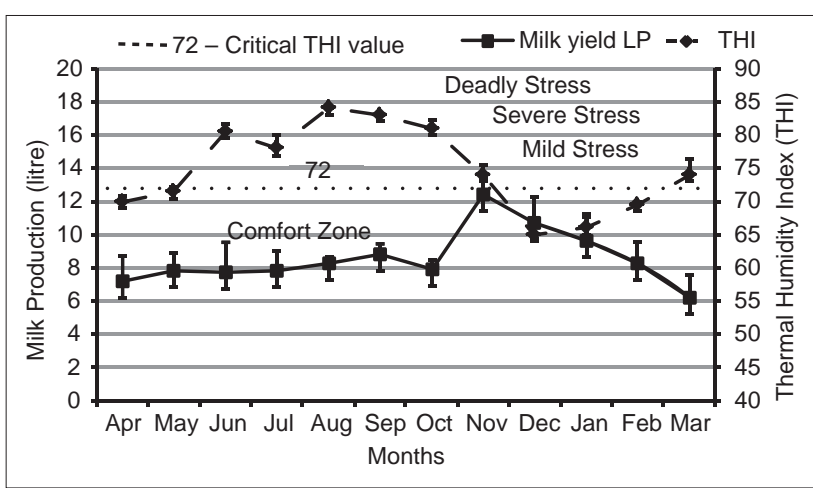

Figure-4: Relation between average milk yield low yielding cow and average thermal humidity index for the experimental months in Dehradun district of Uttarakhand shows that there is no significant effect of heat stress on milk production.

of high yielding dairy cattle to heat stress could be explained by the substantial increase in metabolic heat output these cows are experiencing due to the high milk production [6], which may exacerbate the problem of heat stress in high yielding dairy cows. The exotic Holstein crosses are uncomfortable above the temperature of $25^{\circ} \mathrm{C}$ depending upon the increase in temperature and increase in humidity. When the Cattle Heat Stress Index is at 71 or below, cattle are in the thermal neutral zone, i.e., 72 was optimum, below this animals are in the zone of comfort. Values ranging from 72 to 80 indicate "mild stress." Heat stress index values above 80 indicate "severe stress" [11]. In northern India from March onward summer starts but in mid of June the humidity also rises with high temperature, the stress level is also increased. This is also shown in our Figure-1. July-October the animals were in severe stress level. Heat stress reduced daily milk yield of cows along with an increase in THI values. This decrease in milk production can range from 35 to $40 \%$. In the high yielding cows once the milk production decline it not rise and there was a loss of 8-9 L milk every day and this was irreversible lose. In

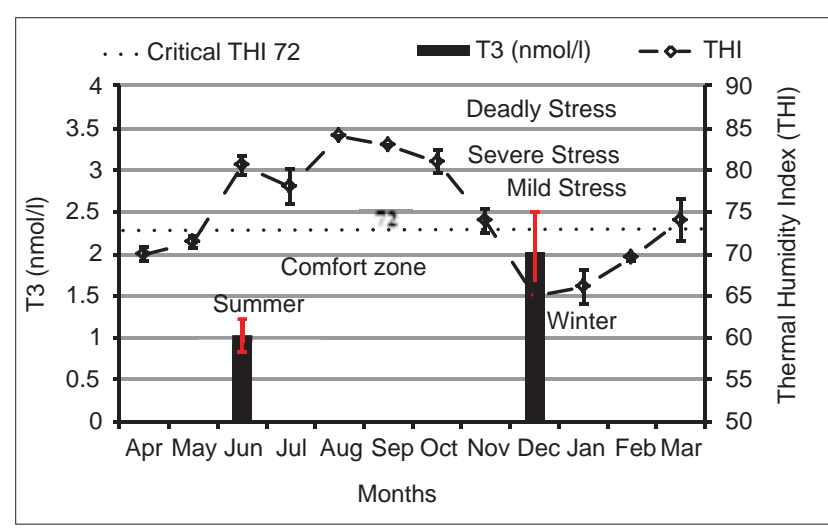

Figure-5: Relation between thyroid (T3, triiodothyronine) hormone level of high yielding cows and thermal humidity index (THI) in summer and winter season shows that due to heat stress in summer months i.e., May, June and July the T3 level declines and in winter months i.e., November, December and January the T3 level rises when the THI decrease to comfort zone.

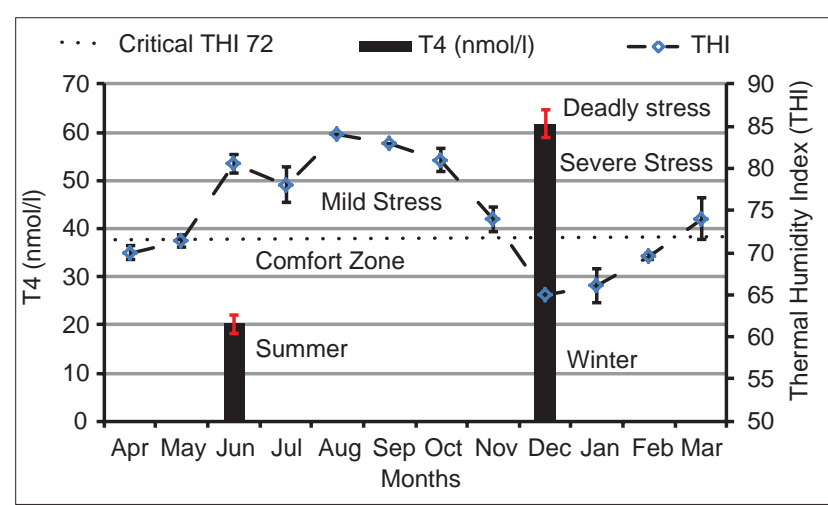

Figure-6: Relation between thyroid ( $T 4$, thyroxine) hormone level of high yielding cows and thermal-humidity index (THI) in summer and winter season shows that due to heat stress in summer months i.e. May, June and July the T4 level declines and in winter month i.e. November, December and January the T4 level rises when the THI decrease to comfort zone.

the low yielding cows producing $<8$ or $10 \mathrm{~L}$ of milk, they are not much affected by increase in THI or stress level. The upper critical temperature for Holsteins is $25-26^{\circ} \mathrm{C}[12]$; cows decrease milk production when THI exceeds the critical comfort level of $72[13,14]$. Previous studies also showed that heat stress negatively affected the milk yield in dairy cows [15-17]. Higher temperature coupled with high humidity depresses performances of dairy cows by reducing feed intake, growth, reproduction [18-20]. To highlight the extent of economic loss in a herd of about 40 dairy cattle here is an example. In case of 40 lactating dairy cows in non-stress condition, monthly market value of milk production would be 40 (number of animals) $\times 18$ (average milk yield in liter) $\times 30$ (number of days) $\times 40$ (cost in Rs. of per liter milk)=Rs. 864,000. However, in case of dairy cattle under stress the same value decreased to Rs. 480,000 [40 × 10 (average milk yield in stress condition) $\times 30 \times 40$ ]. This loss is staggering when we talk about yearly scale. Hence, the investment into proper cattle is worth doing. 
Hormones in plasma are important as a potential indicator of the physiological status of a cow. Environmental temperature, especially high temperature, is depressing the thyroid function. The concentrations of T3 and T4 in blood plasma were found to decline under heat stress condition by up to $25 \%$ [21,22]. It takes several days for T3 and T4 level to reach a new steady state [23]. The readjustment in thyroid response is chronic and as a result, summer thyroid activity is consistent with decrease in metabolic rate, feed intake and growth and milk production under heat stress $[16,18,24]$. Our data also revealed that the lower concentration of thyroid hormones confirms that cows were in heat stress. Adaptation to high temperatures results in an increased body temperature and a decreased thyroid activity $[25,26]$.

\section{Conclusion}

In high yielding cattle, the milk production was affected by $40-44 \%$ due to heat stress. As THI rises from comfort zone to stress zone, milk yield decreased. However in low milk producers no loss in milk yield observed due to heat stress. Hence, it can be concluded that heat stress did not affect the physiology of low yielding cattle. In heat stress condition, the thyroid hormone level was also decreased, whereas in zone of comfort at $72 \mathrm{THI}$ the hormone level increases. It is generally observed that commercial dairy cattle are housed in temporary shed sort of housing in Uttarakhand. If these housing facilities were built scientifically and had small investment in terms of air circulation and cooling, the milk production of these dairy can increase significantly and it can have a major impact on the economic status of dairy farmers.

\section{Authors' Contributions}

UKA and SK designed the experiment, performed research and draft the manuscript. UKA and AT supervised, reviewed and edited the work. All authors read and approved the final manuscript.

\section{Acknowledgments}

The authors would like to thanks Dr. Deepak Raj Arora and Dr. Shailendra Vashisth who kindly provided help in collection of blood samples. We sincerely extend our gratitude to center of excellence in Animal biotechnology, Graphic Era University for providing facilities and financial support throughout the study.

\section{Competing I nterests} interests.

The authors declare that they have no competing

\section{References}

1. Gaughan, J.B., Bonner, S.L., Loxton, I. and Mader, T.L. (2012) Effect of chronic heat stress on plasma concentration of secreted heat shock protein (Hsp 70) in growing feedlot cattle. J. Anim. Sci., 90(9): 2988-2994.
2. Correa-Calderon, A., Armstrong, D., Ray, D., DeNise, S., Enns, M. and Howison, C. (2004) Thermoregulatory responses of Holstein and brown Swiss heat-stressed dairy cows to two different cooling systems. Int. J. Biometeorol., 48(3): 142-148.

3. Hoffmann, I. (2010) Climate change and the characterization, breeding and conservation of animal genetic resources. Anim. Genet., 41(1): 32-46.

4. Cincovic, M.R., Belic Branislava, M., Toholj Bojan, D., Radovic Ivan, V. and Vidovic Bojana, R. (2010) The influence of THI values at different periods of lactation on milk quality and characteristics of lactation curve. J. Agric. Sci., 55(3): 235-241.

5. Kadzere, C.T., Murphy, M.R., Silinikove, N. and Maltz, E. (2002) Heat stress in lactating dairy cows: A review. Livest. Prod. Sci., 77(1): 59-91.

6. West, J.W., Mullinix, B.G. and Bernard, J.K. (2003) Effects of hot, humid weather on milk temperature, dry matter intake, and milk yield of lactating dairy cows. J. Dairy Sci., 86(1): 232-242.

7. Akyuz, A, Boyaci, S. and Cayli A. (2010) Determination of critical period for dairy cows using thermal humidity index. J. Anim. Vet. Adv., 9(13): 1824-1827.

8. Du Preez, J.H., Gieseeke, W.H. and Hattingh, P.J. (1990) Heat stress in dairy cattle and other livestock under Southern African condition. I. Temperature - Humidity index mean values during the four seasons. Onderstepoort J. Vet., 57: 243-248.

9. Bohmaova, J., Misztal, I. and Cole, J.B. (2007) Thermal humidity indices as indicator of milk production losses due to heat stress. J. Dairy Sci., 90: 1947-1956.

10. Oltenacu, P.A. and Broom, D.M (2010) The impact of genetic selection for increased milk yield on the welfare of dairy cows. Anim. Welf., 19: 39-49.

11. Gantner, V., Mijic, P., Kuteroval, K., Solic, D. and Gantner, R. (2011) Thermal humidity index values and their significance on daily production of dairy cattle. Mljekarstvo, 61(1): 56-63.

12. Berman, A., Folman, Y., Kaim, M., Mamen, M., Hertz, Z., Wolfenson, D., Arieli, A. and Graber, Y. (1985) Upper critical temperatures and forced ventilation effects for high yielding dairy cows in a subtropical climate. J. Dairy Sci., 68: $1488-1495$.

13. Ravagnolo, O. and Miztal, I. (2000) Genetic component of heat stress in dairy cattle parameter estimation. J. Dairy Sci., 83(9): 2126-2130.

14. Lambertz, C., Sanker, C. and Gauly, M. (2014) Climatic effects on milk production traits and somatic cell score in lactating Holstein Friesian cows in different housing systems. J. Dairy Sci., 97(1): 319-329.

15. Ghavi-Hossein-Zadeh, N., Mohit, A. and Azad, N. (2013) Effect of thermal humidity index in productive and reproductive performances of Iranian Holstein cows. Iran. J. Vet. Res., 14(2): 106-112.

16. Lacetera, N., Segnalini, M., Bernabucci, U., Ronchi, B., Vitali, A., Tran, A., Guis, H., Caminade, C., Calvete, C., Morse, A., Baylis, M. and Ardone, A. (2013) Climate induced effects on livestock population and productivity in the Mediterranean area. In: Navarra, A. and Tubiana, L., editors. "Regional Assessment of Climate Change in the Mediterranean”, Advances in Global Change Research. Vol. 51. Springer Science + Business Media, Dordrecht, Netherlands, p135-156.

17. Dunn, R.J.H., Mead Naomi, E., Willett Kate, M. and Parker David, E. (2014) Analysis of heat stress in UK dairy cattle and impact on milk yields. Environ. Res. Lett., 9(6): 064006.

18. O’Brien, M.D., Rhoads, R.P., Sanders, S.R., Duff, G.C. and Baumgard. L.H. (2010) Metabolic adaptations to heat stress in growing cattle. Domest. Anim. Endocrinol, 38: 86-94.

19. Crescio, M.I., Forastiere, F., Maurella, C. and Ingravalle Fand Ru, G. (2010) Heat related mortality in dairy cows: A case crossover study. Prev. Vet. Med., 97: 197-7. 
20. Wheelock, J.B., Rhods, R.P., VanBaale, M.J., Sanders, S.R. and Baumgard, L.H. (2010) Effects of heat stress on energetic metabolism in lactating Holstein cows. J. Dairy Sci., 93: 644-655.

21. Mugdub, A., Johnson, H.D. and Belyea, R.L. (1982) Effect on environmental heat and dietary fibre on thyroid physiology of lactating cows. Int. J. Biometeorol., 25: 2323-2329.

22. Beede, D.K. and Collier, R.J. (1986) Potential nutritional strategies for intensively managed cattle during thermal stress. J. Anim. Sci., 62: 543-554.

23. Kamal, I. and Ibraim, I.I. (1969) The effect of natural environment of the Sahara and controlled climate on thyroid gland activity in Friesian cattle and water buffaloes. Int. J. Biometeorol., 13: 275-285.

24. Hansen, P.J. (2009). Effect of heat stress on mammalian reproduction. Philos. Trans. R. Soc, B, 364(1534): 3341-3350.

25. Morais, D.A.E.F., Maia,A.S.C., Silva, R.G., Vasconcelos,A.M., Lima, P.O. and Guilhermino, M.M. (2008) Annual thyroid hormone variation and thermoregulators traits of milk cows in hot environment. Rev. Bras. Zootech., 37(3): 538-545.

26. Agarwal, A. and Upadhay, R. (2013) Heat stress and hormones. Heat Stress and Animal Productivity. Springer, India, p27-51.

\section{$* * * * * * * *$}

